\title{
DEVELOPMENT OF STANDARD OPERATING PROCEDURES AND THEIR INTRODUCTION IN COMPOUNDING PHARMACIES
}

\author{
O.A.Zdoryk \\ National University of Pharmacy
}

Key words: standard operating procedure; compounding preparations; quality assurance of medicines

\begin{abstract}
In accordance with the requirements of good manufacturing practices a proper keeping of documentation in compounding pharmacies licensed to prepare medicines should be an integral part of the quality assurance system and be a key element at all stages of preparation and quality control of compounding preparations. One of the important elements of proper documentation is the practice of using standard operating procedures (SOPs). The aim of this article is to describe the methodology of the SOP developing for licensed compounding pharmacies. Standard procedures should be developed according to the current regulatory framework and research. SOPs are developed by the staff involved in introduction of this procedure. SOPs should be reviewed by responsible persons and approved by the head. The following SOP structural elements have been identified: the title page (the name of institution, the name of the SOP, the classification number, the SOP version, the date on which the SOP enters into force, the signature of the responsible person); the goal; the scope of application; responsibility; stages of the procedure; revision (the term when the SOPs should be reviewed). The organizational structure of the quality assurance system is proposed for the SOP systematization: quality assurance, personnel, facilities and equipment, documentation, technology of preparation, quality control, carrying out works under the contract, complaints and recall, self-inspection. For each of the sections it has been proposed to develop SOPs focused on ensuring compliance with the procedure and to provide the quality aspect, which is the subject in this section.
\end{abstract}

According to the GPP requirements a good documentation in compounding pharmacies is an integral part of the quality assurance system and is a key element at all stages of preparation and quality control of compounding preparations $(\mathrm{CP})[1,2,6,13]$. The purpose of existence and introduction of a good documentation must be determination, management, control and recording of all activities that may directly or indirectly affect all aspects of the CP quality [6]. The important element of a good documentation is the practice of using standard operating procedures (SOPs). The development of SOPs provides the requirements for preparation of the $\mathrm{CP}[1,2]$, but it is not widely introduced into practice of compounding pharmacies of Ukraine.

According to the international experience in GPP introduction SOPs and working instructions should be developed for works and services carried out and available in compounding pharmacies, and which may affect the quality of public service and CP [7-10]. The special attention is paid to development of step-by-step procedures of compounding, quality control, labeling, storage of the $\mathrm{CP}$, cleaning, disinfection, qualifications and operation with the equipment, etc. $[10,11]$. The necessity of the SOP development and introduction in the compounding pharmacies of Ukraine has been confirmed by the results of the survey $[5,14]$.

The introduction of SOPs has a number of advantages. It helps to understand the process better, to optimize the working time and avoid additional unnecessary actions; to define duties of each employee and make sure that every employee knows them; to allow coordi- nating the implementation and sequence of the various stages of work, it provides proper execution of procedures at all stages of preparation, quality control, patient care, etc. SOPs can be also used as an educational tool for temporary workers, part-time workers, as the material for training of new employees, interns, and trainees. The SOP complex introduction should provide quality of the final product, confidence and coordination of operations. The SOP may contain additional information that is necessary for the self-inspection or audit. Standardization of the in-house quality control procedures requires the special attention [5, 14]. In the work [4] some aspects of the SOP development for retail pharmacies are given, approaches for development of the structure, the content and registration are discussed, as well as the list of typical SOPs is formed. For compounding pharmacies of Ukraine the question of the SOP development has been insufficiently studied; therefore, the additional studies are important.

The aim of this article is to describe the methodology of the SOP developing for licensed compounding pharmacies of Ukraine.

Materials and Methods

The study was performed using modern literature sources, the regulatory framework of Ukraine, data of pharmacopoeias and materials of own research. The methods of analysis, synthesis and data compilation were used in the work.

\section{Results and Discussion}

SOP development. While writing the SOP the author should use the current regulatory framework (Laws of 
The list of typical SOPs for compounding pharmacies

\begin{tabular}{|l|l|}
\hline Name of the section & \multicolumn{1}{|c|}{ Examples and subjects of SOPs } \\
\hline Quality assurance & $\begin{array}{l}\text { General procedures; the main stages of organizing the quality assurance system and good } \\
\text { pharmaceutical practice, quality control; administrative responsibilities; writing the SOPs }\end{array}$ \\
\hline Personnel & $\begin{array}{l}\text { Staff recruitment; training; administrative responsibilities; the order to provide information to } \\
\text { the public; consultations of physicians; CP dispensing; occupational hygiene }\end{array}$ \\
\hline $\begin{array}{l}\text { Facilities and } \\
\text { equipment }\end{array}$ & $\begin{array}{l}\text { The care procedure in terms of compounding, quality control, storage of CP; cleaning; registra- } \\
\text { tion of temperature and humidity in the premises; compliance with the sanitary and epidemio- } \\
\text { logical requirements; purchase, maintenance, cleaning of the equipment; provision of analyti- } \\
\text { cal equipment operation }\end{array}$ \\
\hline Documentation & The procedure for filling and storage of documentation \\
\hline $\begin{array}{l}\text { Technology of } \\
\text { preparation }\end{array}$ & $\begin{array}{l}\text { Preparation of active substances and excipients; compounding operations; obtaining of puri- } \\
\text { fied water; preparation of glassware, material for closure; storage; packaging, labeling; the } \\
\text { order of actions in emergencies }\end{array}$ \\
\hline Quality control & $\begin{array}{l}\text { The procedure for the in-house quality control; weighing on an analytical balance; potentio- } \\
\text { metric determination of pH }{ }^{[8]} ; \text { acid-base titration using the colour indicator solution, etc. }\end{array}$ \\
\hline $\begin{array}{l}\text { Carrying out works } \\
\text { under the contract }\end{array}$ & $\begin{array}{l}\text { Contract signing; repair works; external audit; quality control in an independent laboratory; } \\
\text { sampling and transport }\end{array}$ \\
\hline Complaints and recall & Storage of the raw material; managing customer complaints, conflict resolution; side effects of CP \\
\hline Self-inspection & $\begin{array}{l}\text { The procedure for self-inspection; the SOP review procedure; compliance with the require- } \\
\text { ments of SOPs; assessment of the premises and equipment }\end{array}$ \\
\hline
\end{tabular}

Ukraine, orders of the Ministry of Public Health, and requirements of the State Pharmacopoeia of Ukraine), the literature (scientific publications, reference books), manuals for equipment and take into account the experience of the personnel involved in performance of this procedure. The SOP content should be unambiguous for understanding; it should not contain false and unnecessary information.

According to the modern recommendations for the SOP development an author must answer six questions: "Who?", "What?", "When?", "Where?", "Why?", "How?" [11]. In order to answer to the question "Who?" it is necessary to write the name of the person who is responsible for performing the procedure itself or for the procedure's control; "What?" - describe briefly the procedure to be performed and the resources required; "When?"determine the timing of the procedure; "Where?" - give the department's name, premises, in which the procedure should be carried out; "Why?" - give the aim of the procedure; "How?" - describe the order / sequence of performing the task. After receiving the answers to these six questions, the document shall be filled according to the SOP format.

The SOPs developed must be signed by responsible persons of the compounding pharmacy and approved by the legal entity or individual entrepreneur. The SOPs should be developed for each workplace depending on the duties performed by employees of the pharmacy. Since the production capabilities of various pharmacies are different, the content of the SOPs can not be the same for all pharmacies. The mandatory list of the SOPs must be designed for each compounding pharmacy. It is advisable to give the content of SOPs in the form of tables and/or algorithms.

SOP approval. The written SOPs must be revised. A staff member who was not involved in writing the
SOPs should be appointed to review the SOPs. During the SOPs review some questions should be asked: "Have the following six questions (who, what, when, where, why, how) been answered? Are there any restrictions to use the SOP? Has there been something missed?" After the final review the SOP must be approved and signed specifying the date.

All SOPs developed must be registered in the logbook [4] where the SOP name, the registration number, version, the name (position) of the person who developed the SOPs, the name (position) of the person who approved the SOPs, the number of the SOP copies, the place of storage should be noted.

Revision. It is necessary annually to review the relevance of the SOP content, steps/procedures, equipment, etc. If the data is outdated, SOPs should be updated. The SOPs should be also reviewed by employees who directly perform the appropriate procedure, but not by the responsible person developed this SOP. The revised SOPs must be recorded in the SOP registration logbook.

Today there is no form legally approved for SOPs in Ukraine, therefore, each compounding pharmacy can develop SOPs in its own way. However, a certain format and structure of the SOP should be followed $[3,9]$. The mandatory SOPs elements are: the title (name of the institution, the name of the SOP, ID number, the version of the SOP, the date of the SOP approving, the signature of the responsible person); the goal; the scope; the responsibility (who performs and who is responsible for the execution, who is responsible for admission of the staff to perform this procedure, and who has the right to replace the employee to perform the procedure); the stages of the procedure; review (valid date, date of review).

Additional information may include the data about the version of the SOPs (developed first, updated, re- 
placement of the old SOPs); reference (in the reference books, regulatory and normative documents, etc.); term definitions; materials and equipment; safety. These data can be distinguished as the individual structural elements [12].

SOP systematization. It is appropriate to use the organizational structure of the quality assurance system for the SOP systematization in compounding pharmacies of Ukraine. This structure is given in the guideline for preparation of medicines in healthcare institutions
$[13,14]$. It is proposed to develop SOPs for each section. The list of typical SOPs for the quality assurance system in compounding pharmacies is given in Table.

CONCLUSIONS

This article presents the methodology of the SOP development for compounding pharmacies of Ukraine. The algorithm of development, approval and revision procedures of SOPs, the structure and the content of a typical SOP, as well as the systematization system have been proposed.

\section{REFERENCES}

1. Вимоги до виготовлення нестерильних лікарських засобів в умовах аптек: Метод. рекоменд. / За ред. О.І.Тихонова, Т.Г.Ярних. - К.: МОЗ України, 2005. - 98 с.

2. Вимоги до виготовлення стерильних лікарських засобів в умовах аптек: Метод. рекоменд. / За ред. О.І.Тихонова, Т.Г.Ярних. - К.: МОЗ України, 2005. - 76 с.

3. Доброва В.С., Зупанещь К.О., Ратушна К.Л. // Клінічна фармація. - 2013. - Т. 17, №3. - С. 16-20.

4. Ейбен Г.С. Принципи функиіонування системи якості суб' єктів фармацевтичної діяльності: Автореф. дис. ... канд. фармаи. наук: спец. 15.00.01 «Технологія ліків, організація фармацевтичної справи та судова фармачія». - K., 2011. - 26 с.

5. Здорик А.А., Штримайтис О.В., Георгияни В.А. // Вестник фармащии (Витебск). - 2014.- T. 63, №1. C. 16-21.

6. Настанова СТ-Н МОЗУ 42-4.0:2014. - Лікарські засоби. Належнна виробнича практика / М.Ляпунов, О.Безугла, М.Пасічник та ін. - К.: МОЗ України, 2014. - 302 с. - Режим доступу до настанови: httр:// www.moz.gov.ua.

7. Постановление Министерства здравоохранения Республики Беларусь от 31.10.2007 2. №99 «Об утверждении Надлежащей аптечной практики» [Електронний ресурс] - Режим доступу до сайту: http://www.lawbelarus.com/ repub2008/sub09/text09899.htm.

8. Стандартна операційна процедура потенціометричного визначення рН в умовах аптеки: інформаиійний лист про нововведення в системі охорони здоров'я №119 - 2014 / В.А.Георгіяни, О.А.Здорик, O.В.Штрімайтіс. - K., 2014. - Bun. 39. - 8 c.

9. A guide for compounding practitioner USP 35 - NF 30. - The United States Pharmacopeial Convention. Rockville, 2012. -317 .

10. Allen L.V.Jr. // IJPC. - 2002. - Vol. 6, №3. - P. 224-225.

11. Ashworth L.D. // IJPC. - 2007. - Vol. 11, №3. - P. 226-229.

12. Langley C.A., Belcher D. Applied Pharmaceutical Practice $2^{\text {nd }} e d$. - Philadelphia.: PhP, 2012. - $196 p$.

13. PIC/S Guide to Good Practices for the Preparation of Medicinal Products in Healthcare Establishments / Ed. by PIC/S Secretariat. - 2014. - $56 \mathrm{p}$.

14. Zdoryk O.A. // Вісник фармачіï. - 2014. - T. 80, №4. - C. 64-68.

\section{РОЗРОБКА СТАНДАРТНИХ ОПЕРАЦІЙНИХ ПРОЦЕДУР ТА ЇХ ВПРОВАДЖЕННЯ У ВИРОБНИЧИХ АПТЕКАХ \\ O.А.Здорик \\ Ключові слова: стандартна операційна процедура; лікарські засоби аптечного}

виготовлення; забезпечення якості лікарських засобів

Відповідно до вимог належної виробничої практики належне ведення документації у аптеках, що мають ліцензію на виготовлення лікарських засобів, має становити невід'ємну частину системи забезпечення якості та бути ключовим елементом на всіх стадіях виготовлення та контролю якості екстемпоральних лікарських засобів. Одним з важливих елементів належного ведення документації є практика використання стандартних операційних процедур (СОП). Метою даної роботи є виклад методології розробки СОП для аптек, що мають ліцензію на виготовлення лікарських засобів. Стандартні процедури мають розроблятися з урахуванням сучасної нормативної бази та наукових досліджень персоналом, який залучений до виконання даної процедури. СОП мають бути прорецензовані відповідальними особами та затверджені керівником. Виділені наступні структурні елементи СОП: титул (назва установи, назва СОП, класифікаційний номер, версія СОП, дата, з якої СОП набувають чинності, підпис відповідальної особи); мета; сфрера застосування; відповідальність; стадії процедури; 
перегляд (термін дії, коли СОП мають бути переглянуті). Для систематизації СОП запропоновано використовувати організаційну структуру системи забезпечення якості: забезпечення якості, персонал, приміщення та обладнання, документація, технологія виготовлення, контроль якості, проведення робіт за контрактом, скарги та відкликання, самоінспекція. Для кожного з розділів пропонується розробляти СОП, орієнтовані на забезпечення виконання тієї процедури і забезпечення того аспекту якості, якому присвячено цей розділ.

\section{РАЗРАБОТКА СТАНДАРТНЫХ ОПЕРАЦИОННЫХ ПРОЦЕДУР И ИХ ВНЕДРЕНИЕ В ПРОИЗВОДСТВЕННЫХ АПТЕКАХ \\ A.А.Здорик}

Ключевые слова: стандартная операционная процедура; лекарственные средства аптечного приготовления; обеспечение качества лекарственных средств

В соответствии с требованиями надлежащей производственной практики, надлежащее ведение документации в аптеках, имеющих лицензию на приготовление лекарственных средств, должно составлять неотъемлемую часть системы обеспечения качества и быть ключевым элементом на всех стадиях приготовления и контроля качества экстемпоральных лекарственных средств. Одним из важных элементов надлежащего ведения документации является практика использования стандартных операционных процедур (СОП). Целью данной работы является изложение методологии разработки СОП для аптек, имеющих лицензию на приготовление лекарственных средств. Стандартные процедуры должны разрабатываться с учетом современной нормативной базы и научных исследований персоналом, который вовлечен в выполнение данной процедуры. СОП должны быть прорецензированы ответственными лицами и утверждены руководителем. Выделены следующие структурные элементы СОП: титульная страница (название учреждения, название СОП, классифрикационный номер, версия СОП, дата, с которой СОП вступает в силу, подпись ответственного лица); цель; сфрера применения; ответственность; стадии процедуры; пересмотр (срок действия, когда СОП должны быть пересмотрены). Для систематизации СОП предложено использовать организационную структуру системы обеспечения качества: обеспечение качества, персонал, помещение и оборудование, документация, технология приготовления, контроль качества, проведение работ по контракту, жалобы и отзывы, самоинспекция. Для каждого из разделов предлагается разрабатывать СОП, ориентированные на обеспечение выполнения той процедуры и обеспечение того аспекта качества, которому посвящен этот раздел. 